\title{
エマルション中に形成さ扎る二次粒子 ——形成機構と物性への影響
}

\author{
（1982 年 9 月 1 日受 理）
}

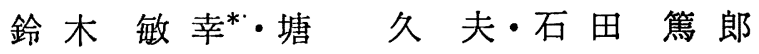

$\mathrm{O} / \mathrm{W}$ エルション中にある条件下で乳化粒子の凝集体（二次粒子）が形成された。この二次粒子は高 級アルコールが存在するときに形成される傾向にあったので非イオン界面活性剂/高級アルコール/流動 パラフィン/水からなる乳化系について二次粒子の形成条件, 構造, 形成機構および二次粒子形成がェ マルション物性に扰よぼす影響について検討を行なった。その結果, 二次粒子は界面活性剤/高級アル コール/水からなる閉じたラメラ型液晶により乳化粒子が取り囲まれた構造であり，二次粒子の形成に は高級アルコール量および界面活性剤の HLB が特定の範团にあることが必要であった。二次粒子の形 成機構は乳化過程に打ける高級アルコールの溶存状態により説明されることがわかった。また，エマル ションの物性は二次粒子の形成により大きく変化した。たとえば系に降伏值が生じ, クリーミングや合 一に対する安定性がいちじるしく向上し，エマルションからの水分蒸発も抑制された。

これらの絬果は，いずれも連続相中に液晶が形成されることにより，乳化粒子および水が固定された 結果生じたものと考えられる。

\section{1 緒言}

O/W エマルション中に Co-surfactant として高級アルコール を添加することにより，系の安定性が向上し粘度も増すことはよ く知られている。Schulman と Cockbain1) は, 1-ヘキサデカ , ールの添加によりェマルションの安定性が向上するのは油/水界 面に“intermolecular complex”が形成されるためであるとした が，最近では，エマルションの安定化には連続相に形成される液 晶またはゲルが関与するという見解が主流となっている。エマル ションの安定化に対する液晶の寄与に関しては, Friberg ${ }^{2)} か ゙$ 油/ 水界面における van der Waals 力の変化といら理論的立場から 考察を行なっており, 液晶の形成により夜滴の合一に要する van der Waals 力が減少すると述べている。

また，高級アルコール/界面活性剂/水系の相図の研究からは, ある条件下では系中に液晶が形成されることが知られている34) が，高級アルコールが固体の場合でも $\alpha$ 型結晶となる温度領域で は液晶が生成し，この液晶がエマルションの安定化に寄与してい るという報告5)6 もある。さらに高級アルコールはェマルション

花王石睑株式会社東京研究所, 131 東京都墨田区文花

1) J. H. Schulman, E. G. Cockbain, Trans. Faraday Soc., 36, 651(1940).

2) S. Friberg, P. O. Jansson, E. Cederberg, J. Colloid Interface Sci., 55, 614(1976).

3) P. Ekwall, I. Danielsson, L. Mandel, Kolloid Z. Z. Polym., 169, 113(1960).

4) K. Fontell, J. Colloid Interface Sci., 44, 318(1973).

5) S. Fukushima, M. Takahashi, M. Yamaguchi, ibid., 57, 201(1976).

6) S. Fukushima, M. Yamaguchi, F. Harusawa, ibid., 59, 159(1977).
系において self bodying action と呼ばれる増粘作用を示すこと が知られており，Barry らて〜10)は種々の活性剤との組み合わせ について粘弾性挙動の検討を行ない, この増粘作用はエマルショ ン中に形成された液晶が関与するゲルネットワークによるもので あると結論している。

このよらにエマルション中に液晶が形成されると，エマルショ ンの安定性が向上したり, あるいはェマルションの粘度が高まる など実用的に有益な点が多いが，液晶の形成条件や液晶の形成に よりエマルション物性がどのように変化するかなどについては不 明の点も多い。

一方, 著者は非イオン界面活性剂を乳化剂とする $\mathrm{O} / \mathrm{W}$ ェマル ション中に，ある条件下に拈いて乳化粒子の集合体である二次粒 子が形成されることがあり，二次粒子の形成に液晶が関与してい

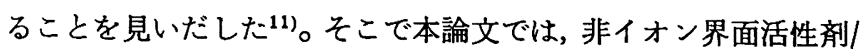
高級アルコール/水/流動パラフィンからなる乳化系において, 二 次粒子の形成条件，二次粒子の構造，二次粒子の形成によるエマ ルション物性の変化および二次粒子の形成に関与する液晶の役割 などについて検討を行ない, エマルションの安定化におよぼす液 晶の寄与について考察を試みた。

\section{2 実験}

2.1 試 料

油相としては流動パラフィン（試薬一級）を用い, 水はイオン

7) B. W. Barry, J. Colloid Interface Sci., 32, 551(1970).

8) B. W. Barry, G. M. Saunders, ibid., 34, 300(1970).

9) B. W. Barry, G. M. Saunders, ibid., 38, 616(1971).

10) B. W. Barry, G. M. Saunders, ibid., 38, 626(1972).

11）鈴木敏幸, 塘 久夫, 河野純一, 石田篤郎, 日本化学会第 42 秋季年会発表 (1980). 
交換水を用いた。界面活性剂としてはオレイン酸モノグリセリ ドおよびポリ(オキシェチレン)ソルビタンモノステアラートを 用いたが、これらは市貶品 ${ }^{12)}$ をくに精製を行なわずそのまま用 いた。高級アルコールとしては，1-ヘキサデカノールと 1-オク タデカノールの重量比で $3: 2$ の混合物である “セトステアリル アルコール”(日局品)を用いた。

\section{2 実験方法}

2.2.1 エマルションの調製: 界面活性剤, 高級了ルコールを 含む油相を $70^{\circ} \mathrm{C}$ に加熱し, 定速プロペラ (500 rpm) でかきま ぜながら $70^{\circ} \mathrm{C}$ の水を徐々に加えて乳化し，その後ただらに冷却 するいわゆる転相乳化法により行なった。

\subsection{2 乳化状態の観察および二次粒子の確認}

（i ）エマルションを直接, または水で希釈したのち光学顕微 鏡により観察した。顕微鏡は日本光学製 XF-2 型を用いた。

(ii) $25^{\circ} \mathrm{C}$ に日間放置したエマルションを $0.9 \%$ 塩化ナト リウム水溶液で 1000 10000 倍に希釈したのち, Coulter Counter Model TA-II を用いて粒径分布を測定することにより行 なった。

とくに二次粒子の形成は，水で希釈したエマルションを顕微鏡 で観察したときに乳化粒子の策合体が見られること, Coulter Counterによる粒径分布曲線に分布の山が二つ見られることによ り確認を行なった。

\subsection{3 液晶の観察と液晶構造の確認}

(i) 直交ニコル下に护ける偏光顕微鏡組織像 (Texture) に より液晶の形態, 構造をある程度分類することができる1314)の で, 偏光顕微鏡観察により液晶構造の推定を行なった。すなわち 各試料約 $50 \mathrm{mg}$ をスシイドグラス上に約 $1 \mathrm{~cm}^{2}$ の広さにうすく のばし, 試料の周囲にシリコーングリースを慗布し，カバーグラ スで上面をおおって試料を密封したのら, 直交ニコル下で観察し た。

（ii）液晶の確認および構造決定にはX線回折がもっとも確実 な方法であり ${ }^{15) 16)}$, 本研究に执いても最終的な状態拈よび構造の 判定にはX線回折法を用いた。小角領域の測定には Kratky U一 スリットカメラを用い, 試料をマイカ空の付いた金属セルに封入 し, position sensitive proportional counter ${ }^{17) 18)}$ により散乱強 度を検出した。をた広角領域の測定には島津自記 $\mathrm{X}$ 線回折装置 VD-1A 型を用いた。なお X 線はどちらの場合も $\mathrm{Cu} K_{\alpha}$ 線 ( $\lambda=1.54 \AA$ 只 を用いた。

2.2.4 エマ・ルション物性の測定と比較：二次粒子形成による エマルション物性の変化は, 降伏值, 見かけ粘度などのレオロジ 一特性, エマルションの安定性, エマルションからの水分蒸発速

12）オレイン酸モノグリセリド：花王アトラス(株)製 ATMOS 300.

ポリ(オキシェチレン)ソルビタンモノステアラート：花王 アトラス(株)製 TWEEN 60.

13) F. B. Rosevear, J. Am. Oil Chem. Soc., 31, 628(1954).

14) A. Saupe, J. Colloid Interface Sci., 58, 549(1977).

15) V.Luzzati, F. Musson, J. Cell Biol., 12, 207(1962).

16) S. Friberg, "Food Emulsions", Chap. 2 and 3, Marcel, Dekker, New York (1976) p. 39 139.

17) C. J. Burkowski, M. K. Kopp, Rev. Sci. Instrum., 39, 1515(1968).

18) E. Wada, K. Kurita, H. Tagawa, H. Hiramatsu, T. Suzuki, S. Yonezawa, Rep. Prog. Polym. Phys. Jpn., XVIII, 65(1975).

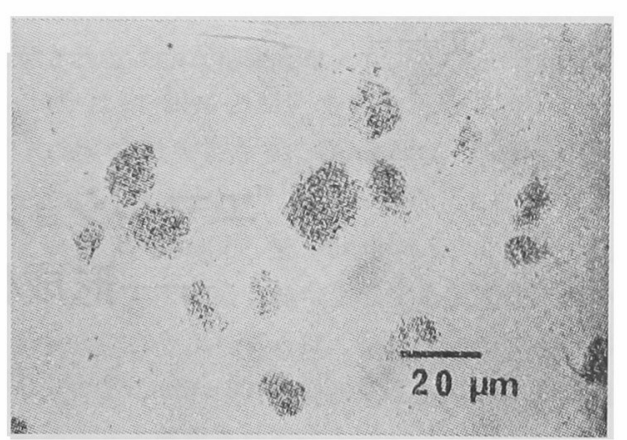

Fig. 1 Photomicrograph of secondary droplets (aggregates of emulsion droplets)

Magnification $\times 200$

度を比較することにより求めた。レオロジー特性の測定には二重 円筒型回転粘度計 (Haake 社 Haake-Rotovisco RV-2) を用い た。エマルションの安定性は, 各エマルションを $25^{\circ} \mathrm{C}$ および $40^{\circ} \mathrm{C}$ の恒温下に 7〜60 日間放置し, 相分離の状態を観察するこ とにより比較した。エマルションからの水分蒸発は, エマルショ ンを一定の厚さ $(0.8 \mathrm{~mm})$ に皿状の容器に充媜し, 温度 $25^{\circ} \mathrm{C}$, 相対湿度 $54 \%$ の条件下に放置し, 時間による重量減少を测定す ることにより比較した。

\section{3 結果と考察}

\section{1 二次粒子の形成条件と構造}

非イオン界面活性剂/高級アルコール/流動パラフィン/水から なるエマルション中に, ある条件下で乳化粒子の集合体（以後二 次粒子と呼ぶ）が形成される現象が認められた。二次粒子の形成 は, エマルションを水で希䣋して顕微鏡で観察すると図 1 のよう な乳化粒子の集合体が見られることにより確認される。

二次粒子を形成しない通常のエマルションでは, 乳化粒子は個 々に分散してブラウン運動をしているのに対し，二次粒子が形成 されたエマルションの場合, 二次粒子内部では乳化粒子は固定さ れていた。そこで非イオン界面活性剂/高級アルコール/流動パラ フィン/水の組成が重量比で 4/0 4/24/72 となるような乳化系に おいて, 界面活性剤の HLB 数拉よび高級アルコールの量を変化 させて乳化を行ない, 乳化領域および二次粒子が形成される領域 を求めた。界面活性剤の HLB 数は, オレイン酸モノグリセリド $(\mathrm{HLB}=2.8)$ とポリ(オキシェチレン)ソルビタンモノステアラ ート $(\mathrm{HLB}=14.9)$ の混合比を変えることにより変化させた。得 られた結果を図 2 に示す。

図中実線で囲まれた範围 (I，II，II）が $25^{\circ} \mathrm{C}$ で 7 日保存に拈 いて相分離を生じない安定なェマルションが得られた領域であ り,このうち斜線で示した領域 (I)で二次粒子の形成が観察され た。図から明らかなように, 安定な乳化を与える界面活性郕の HLB 数範囲は高級アルコールの添加量が増すにしたがい高 HLB 数側に移行する傾向が認められたが，これは高級アルコール自身 が親油性の強い乳化剂として作用しているだめであると考えられ る。すなわち非イオン界面活性剂の HLB 数を固定して高級アル コールを加えた場合，高級アルコールの添加量が増すことにより 非イオン界画活性剤/高級アルコール混合乳化剤の HLB は低く なるため，流動パラフィンの乳化所要 HLB をたもつためには非べ イオン界面活性剤の HLB 数は高い方向へ移向する必要があるの 


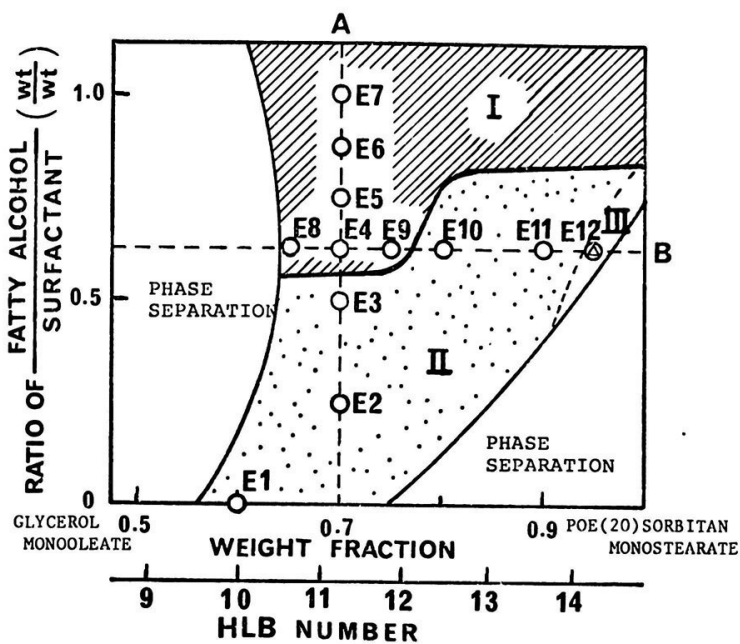

Fig. 2 Formation conditions of secondary droplets in the emulsion

$$
\begin{aligned}
& 0 \text { : Fine emulsion } \\
& \text { (4) } \text { Coarse emulsion } \\
& \text { एIIIA : Secondary droplet formation area } \\
& \therefore: \text { : Stable ordinary emulsion area }
\end{aligned}
$$

であろう。しかしながら，二次粒子が形成されると最適乳化を与 える非イオン界面活性剂の HLB 数範囲は広がった。

図から明らかなように二次粒子は安定乳化領域の中でも高級ア ルコールの割合が非イオン界面活性剂に対し 0.5 以上で形成さ れ，しかも HLB 数が約 10〜15 の範囲でのみ形成された。また 高級アルコール量が少ない場合は, 界面活性剂の HLB 数が低い 領域に形成されやすいことがわかった。高級アルコールの割合が 非イオン界面活性剤に対して 1.0 を越えるとエマルション中に高 級アルコールの結晶の析出が認められた。このことから二次粒子 の形成には乳化剤の HLB が特定の範囲にあること，特よび高級 アルコールの適量の存在が必要条件であることがわかる。

このほか図 2 中領域 (III) で示した範盲内では, 個々の乳化粒子 は（I ）および(II)の領域のエマルションの乳化粒子にくらべて大 きく，良好な乳化状態のェマルションではないのにもかかわらず 相分離は生じなかった。そして顕微鏡観察によると，個々の乳化 粒子が別の物質にとり囲をれた二重棈造をとっている状態が観察 された。

領域 ( I )の二次粒子㧊よび領域 (III)の乳化粒子をとり囲んでい る部分を直交ニュル下の偏光顕微鏡で観察すると，それぞれ図 3, 図 4 のように光学異方性を示す物質の存在が認められた。ま 心，二次粒子の形成されたエマルション（E 4）を $20000 \mathrm{G} 5$ 時 間の条件で遠心分離を行なうと, クリーム相，水相の他，中間層 に透明なゲル状の相が認められた。分離して得た各相をそれぞれ 直交ニコル下で観察すると中間㬝の透明ゲル相にのみ光学異方性 が認められ，組織像はラメラ型液晶に特有な mosaic texture ${ }^{13) 14}$ であった。

さらに，この相が液晶であることを確認するために，広角領 域，小角領域において X 線回折を行なったところ，広角領域か らは $4.5 \AA$ を中心に広いピークが得られ，小俑領域からは図 5

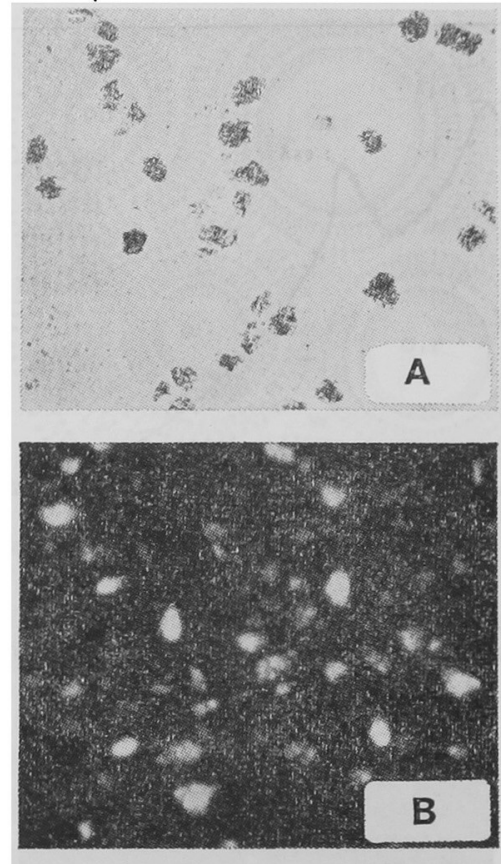

Fig. 3 Photomicrographs of an emulsion in region( I ) of Fig. 2

(A) : In ordinary light (B) : In polarized light Magnification $\times 60$

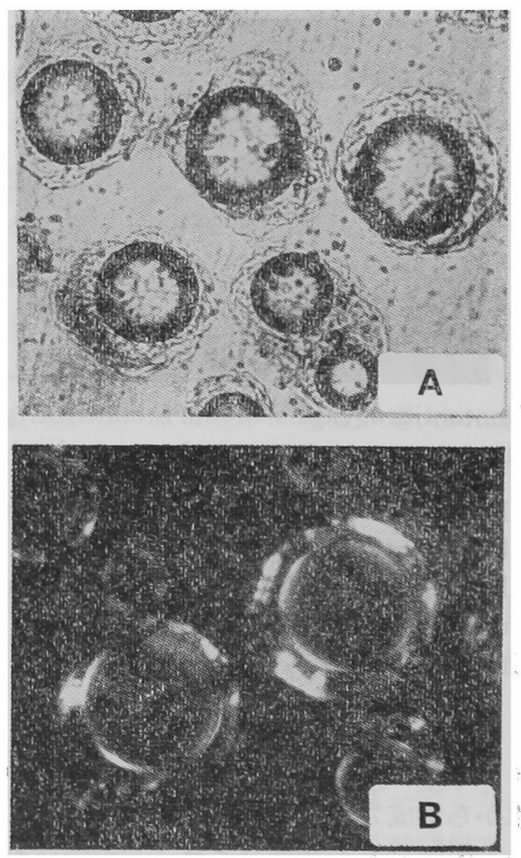

Fig. 4 Photomicrographs of emulsion droplets in region (III) of Fig. 2

(A) : In ordinary light (B) : In polarized light Magnification $\times 60$

に示したように Bragg 間隔で $66 \AA$ および $134 \AA$ に相当する 角度にピークが得られた。この Bragg 間隔の此は $1: 2$ である ことから，この透明ゲル相はラメラ構造をもつ液晶 ${ }^{15) 16) て ゙ あ り ， ~}$ 各ラメラの厚さは $134 \AA ̊$ であることが判明した。この液晶相は 


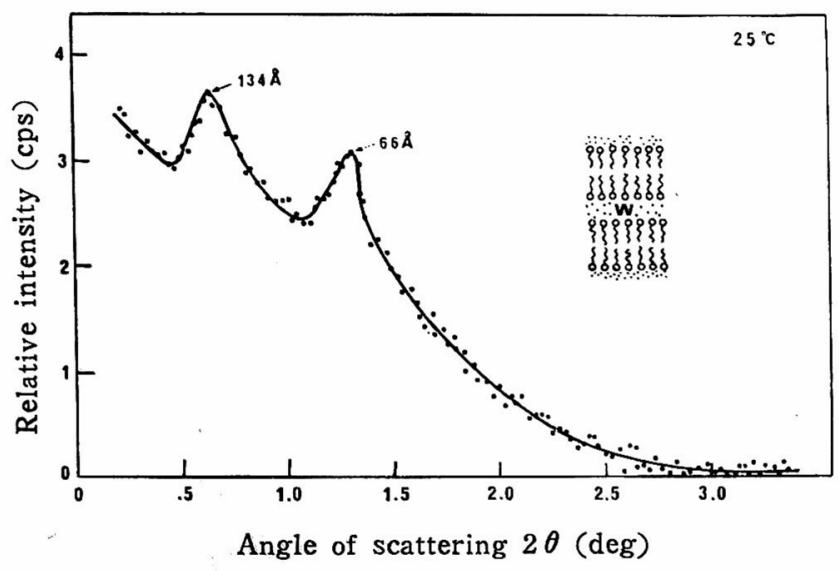

Fig. 5 Small angle $X$-ray scattering curve of gel-like phase in the emulsion (E 4) after centrifugation
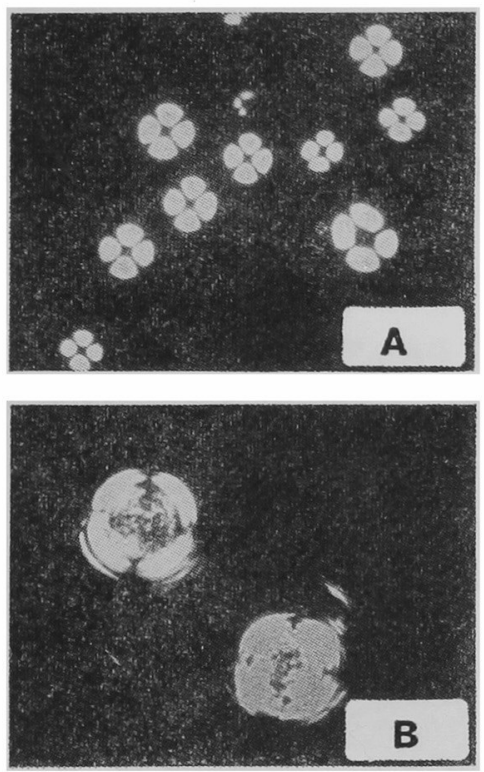

Fig. 6 Photomicrographs of surfactant/fatty alcohol/ water ternary system under polarized light

(A) : Dispersion of liquid crystals of concentric lamella type.

(B) : Dispersion of fatty alcohol crystals surrounded by liquid crystals.

Magnification $\times 200$

流動パラフィンをほとんど含まない非イオン界面活性剂, 高級ア ルコール，水から形成されると考えられる。

そこでェマルションから流動パラフィンを除いた非イオン界面 活性剂/高級アルュール/水の三成分混合物をェマルションを調整 する場合と同じ方法で調製し, $25^{\circ} \mathrm{C}$ で 7 日保存後, 直交ニコル下 の偏光顕微鏡で観察すると図 6-(A), (B) に示すような組織像が 見られた。(A) は閉じたラメラ型液晶 (Concentric Lamella) ${ }^{19}$ の分散した状態であり, 高級アルコール量が比較的少ない昜合に 形成された。高級アルコールの割合が多くなると, 三成分溶液中 には図 6-(B) のように, 液晶の他高級アルコールの結晶も見ら れた。したがって液晶の形成には非イオン界面活性剂と高級アル

19) K. Larsson, Z. Phys. Chem., 56, 173(1967).

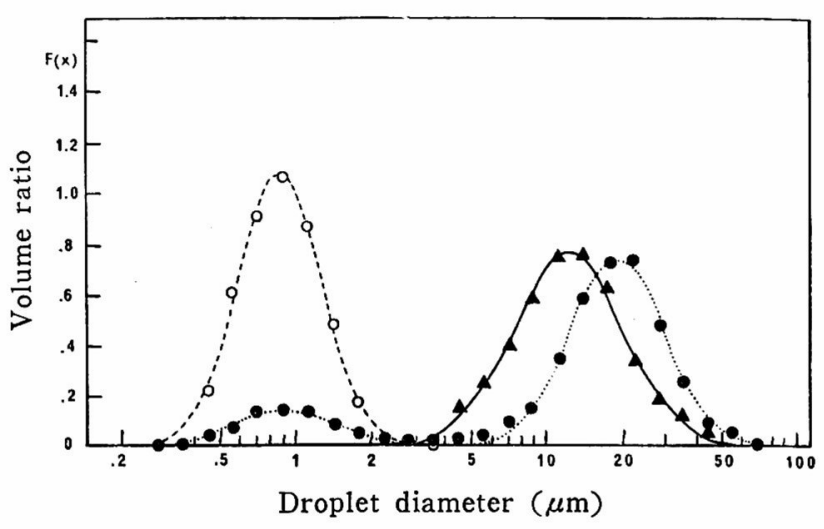

Fig. 7 Size distribution of ordinary emulsion, secondary droplet emulsion, and liquid crystals of three component mixture

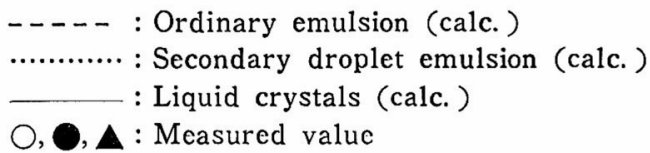

コールの適度なバランスが重要であることがわかる。この閉じた ラメラ型夜晶が形成される領域は図 2 の二次粒子が形成される領 域とは一致せず，二次粒子が形成される領域より高級アルコール の割合がかなり少ない場合でも，三成分溶液中に液晶が形成され た。しかしながら高級アルコールを含まない采, すなわち非イオ ン界面活性剂と水の混合系には閉じたラメラ型液晶は形成されな かった。

これらの事実から，二次粒子の形成には液晶の生成が重要な役 割をしていることが予想されるが，ここで二次粒子と液晶の関係 をさらに理解するため，通常のエマルション（図 2 に拈ける E2）， 二次粒子が形成されたエマルション(図2における4), および E 4 に対応する組成の非イオン界面活性剂/高級アルコール/水の 三成分系の夜晶についてそれぞれ coulter counter により粒度分 布を測定した。測定結果を図 7 に示す。

図中で各点は測定值を示し, 曲線は分布を次式 (1)の対数正規 分布と見なしたときの計算により求めた分布関数である。

$$
\begin{aligned}
f(d)= & \frac{1}{\sqrt{2 \pi} \ln \sigma} \exp \left\{-\frac{1}{2(\ln \sigma)^{2}}(\ln d-\ln u)^{2}\right\} \\
& d: \text { 粒子径 } \\
& u: \text { 平均粒子径 } \\
& \ln \sigma: \text { 対数標準偏差 }
\end{aligned}
$$

二次粒子形成エマルションについては分布の山が二つ存在する ため，分布を二つの対数正規分布の和であると仮定し，(2)式に おいて coulter counter の测定值から Gauss-Newton 法により それぞれの非線型パラメーターを推定し，分布関数を求めだ。

$$
\begin{aligned}
F(x)= & A_{0} \exp \left\{-B_{0}\left(x-M_{0}\right)^{2}\right\} \\
& \quad+A_{1} \exp \left\{-B_{1}\left(x-M_{1}\right)^{2}\right\} \\
& x=\ln d \\
& d: \text { 粒子径 } \\
& A_{0}, A_{1}, B_{0}, B_{1}, M_{0}, M_{1}: \text { 定数 }
\end{aligned}
$$

その結果, いずれの分们も理椧式すなわち対数正规分布にした 


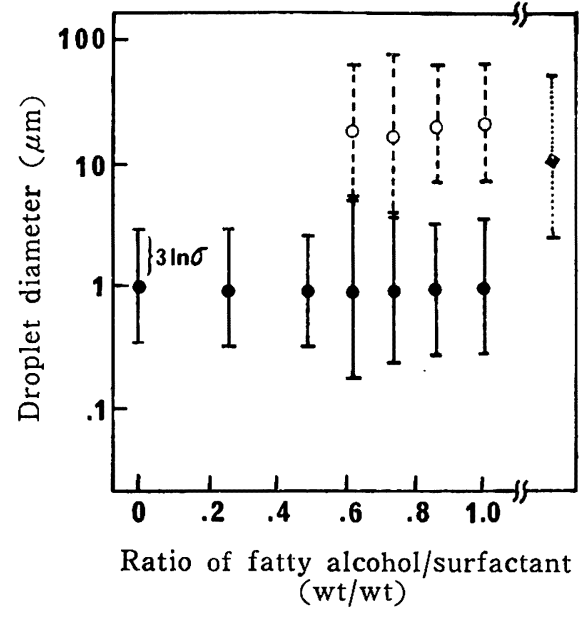

Fig. 8 Means and deviations of droplet diameters of emulsion droplets, secondary droplets, and liquid crystals of concentric lamella type

: Emulsion droplet

$O$ : Secondary droplet

: Liquid crystals

がっていることがわかった。通常のェマルションでは乳化粒子は 粒径 $1 \mu \mathrm{m}$ 前後に分布していたが，二次粒子が形成されたェマ ルションでは真の乳化粒子と考えられる $1 \mu \mathrm{m}$ 前後の一次粒子 の分布の他に $20 \mu \mathrm{m}$ 前後に二次粒子の分布が見られた。この二 次粒子の分布は三成分系の液晶の分布と同様の分布をして和り全 体的に粒径の大きい方へ移行した形となっていた。また図 8 に は，図2において A 軸に沿った E 1〜E 7 のエマルション,すな わち高級アルコールの添加量を変化させた一連のエマルションに つい求めた乳化粒子と二次粒子の平均粒径と粒径の分散状態を 示した。この罒から二次粒子はいずれもほぼ同じ平均粒径と分散 を有しており，さきに述べたよらに液晶の分布より粒径の大きな 方向へ移行していることがわかる。

以上の結果から二次粒子の構造を推定すると，二次粒子は図 9 のモデルのような, 非イオン界面活性剂〜高級アルコール〜水か らなる閉じたラメラ型液晶により乳化粒子がとり囲まれたような 構造であると思われる。

ここで二次粒子の形成機構を考察してみたい。二次粒子の形成 には高級アルコールの存在が不可欠であることから, 高級アルコ ールが液晶の生成に関与していると考えられる。エマルション中 に和ける高級アルコールの存在状態は，

1）油相中に溶解する

2）非イオン界面活性剤とともに油/水界面に配列する

3）非イオン界面活性剤および水とともに液晶を形成する

4） $\beta, \gamma$ 型結晶として析出する

の四つの状態が考えられる。このうち 1),2）の状態は 3),4）に 倀先して存在する。これは非イオン界面活性剂/高級アルコール/ 水からなる三成分系では高級アルコールがわずかでも存在すると 液晶が形成されるのに対し，流動パラフィンを含むェマルション 系では高級アルコールが一定濃度以上存在していないと液晶が形 成されないことからわかる。1）,2）の飽和量以上に高級アルコー ルが存在すると 3）のよらに液晶が形成され，これが二次粒子を 形成させるものと考えられる。

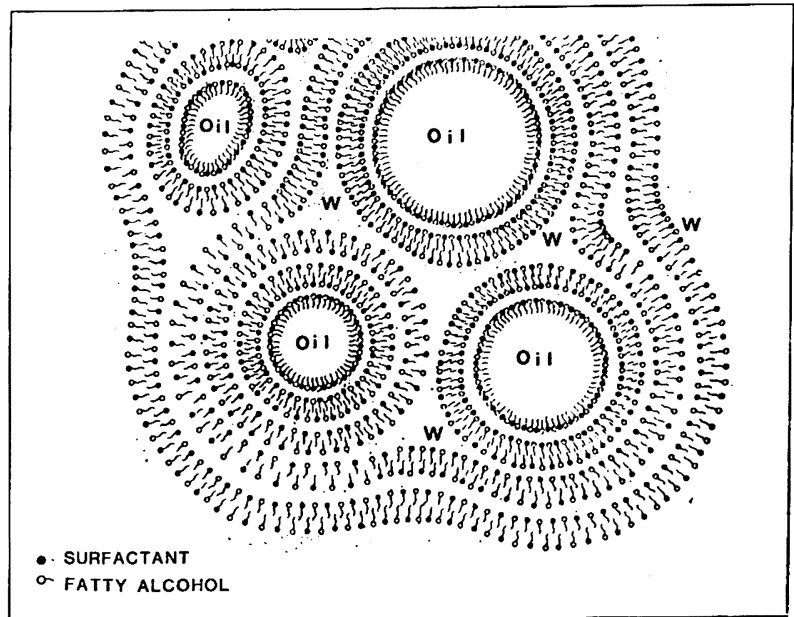

Fig. 9 Schematic illustration of a secondary droplet

また液晶が乳化粒子の周囲にのみ形成される理由は, 乳化後の 冷却過程で乳化滴中に存在している高級アルコールの流動パラフ ィンへの溶解度が低下し，飽和值を越えて乳化粒子の外へ排出さ れ，このさい水相抗よび油/水界面に存在する非イオン界面活性 斉とともに乳化粒子の周囲に液晶を形成するためであろら。

\section{2 二次粒子形成によるエマルション物性の変化}

図 10 に界面活性剤の HLB 数を一定にして, 高級アルュール/ 界面活性剤の比を変えたとき（A），比を一定にして HLB 数を 変化させたとき（B）のェマルションの降伏值と粘度の変化を示 した（ただし，E 1 については E 2〜E 7 と同様，乳化状態の良 好な HLB 数の組成を用いた)。

粘度はずり速度 $400 \mathrm{~s}^{-1}$ のずり応力から求めた見かけ粘度で示 してある。図から明らかなよらに高級アルコールの量を変化させ た場合も非イオン界面活性剂の HLB 数を変化させた場合も，二 次粒子が形成されるとエマルションに降伏值が生じ，また見かけ 粘度もいちじるしく増大した。これは二次粒子の形成すなわち液 晶の形成により乳化粒子拉よび水が固定され，系に構造性が生じ たためと考えられる。また見かけ粘度の増大には液晶の形成によ り連続相の一部が固定され，見かけ上の分散相容積が増加してい ることも寄与していると考えられる。

各エマルションの降伏值, 粘度については $5^{\circ} \mathrm{C}$ およひ $25^{\circ} \mathrm{C} に$ 保存したものについて経日变化を調べた。 $5^{\circ} \mathrm{C} に$ 保存した試料に ついても $25^{\circ} \mathrm{C} に 4$ 時間放置し, 温度が十分一定になったことを 確認したのち測定を行なった。結果は図 11 に示したように, 二 次粒子を形成したェマルションの降伏值は 2 週間ぐらいまでやや 増加する傾向にあったが，その後はほぼ一定となった。二次粒子 が形成されないェマルションの場合，長時間保存したものについ ても降伏值は生じなかった。粘度に関しては，いずれのェマルシ ョンの場合も経時的に一定值を示した。また $5^{\circ} \mathrm{C}$ に保存した試 料についても外観およびレオロジー特性に顕著な変化は認められ なかった。

高級アルコールにより安定化されたェマルションの場合, 高級 アルコールの結晶構造が $\alpha$ 型をとる温度以下では経時的に結晶が 析出し，粘度が低下するといら報告 ${ }^{5 / 6)}$ があるが，本研究に用い たェマルションの場合, 非イオン界面活性剤に対する高級アルコ 一ルの割合が比較的少ないこと，用いた界面活性剂が結晶化しに 


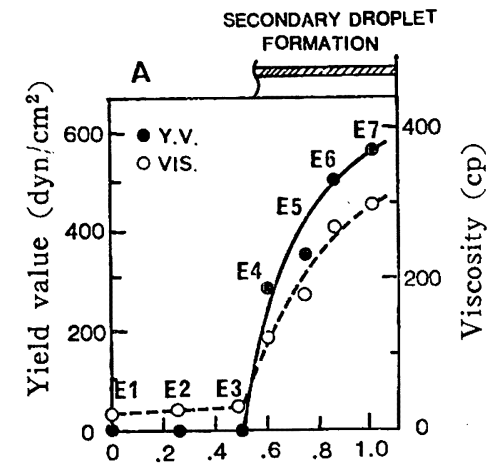

Ratio of fatty alcohol/ surfactant (wt/wt)

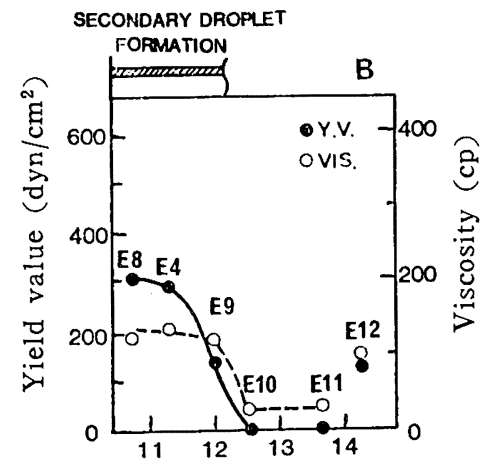

HLB number

Fig. 10 Changes in the rheological properties of emulsions by the formation of secondary droplets

(A) : With fatty alcohol content

(B) : With HLB
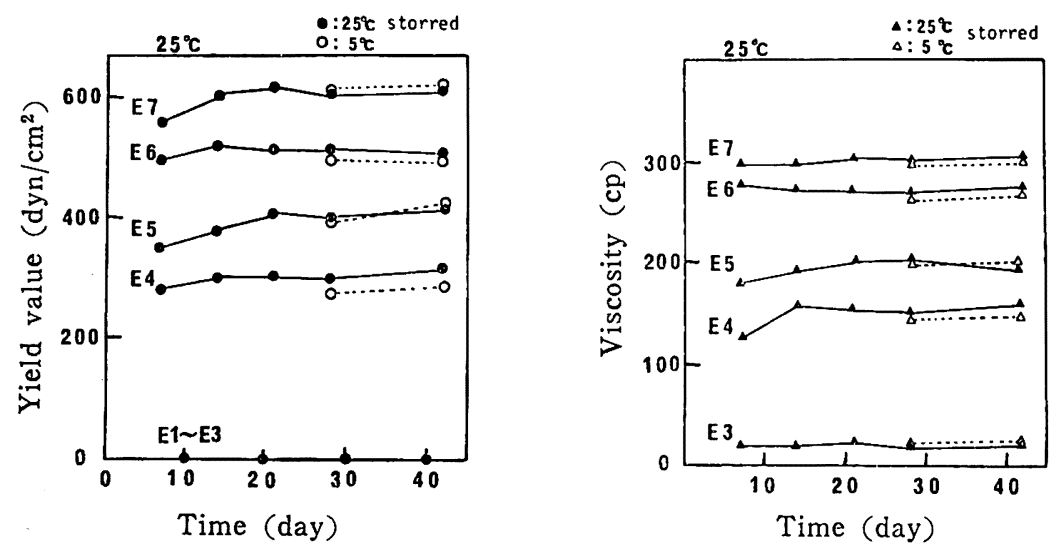

Fig. 11 Changes in the rheological properties in emulsions with time

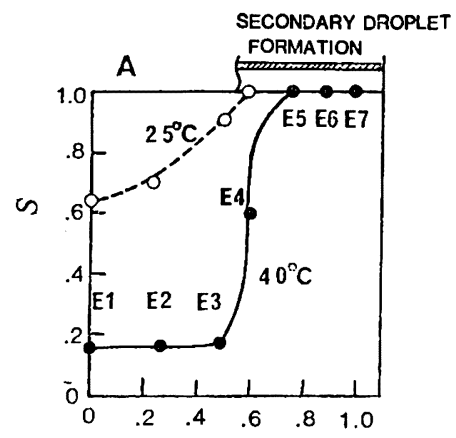

Ratio of fatty alcohol/ surfactant ( $w t / w t)$

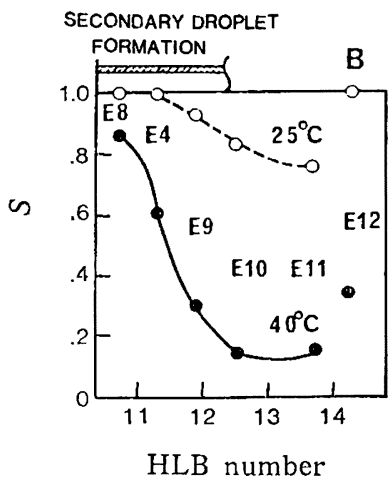

HLB number

Fig. 12 Changes in the stabilities of emulsions against creaming by the formaion of secondary droplets

(A): With fatty alcohol content

(B) : With HLB

$S=1-W_{1} / W_{0}$

$S$ : Stability index against creaming

$W_{0}$ : Volume of water in emulsion

$W_{1}$ : Volume of separated water 
くい酸化ェチレン鎖をもった非イオン界面活性郕であることか ら，高級アルコール単独では $\beta$ または $\gamma$ 型の結晶構造をとる温度 で饬っても高級アルコールを含む混合乳化剈の結晶化は生じなか ったものと思われる。

因 12 には図 10 と同様にして得たエマルションの安定性の测定

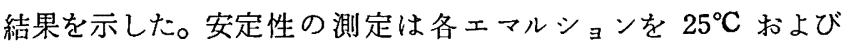
$40^{\circ} \mathrm{C}$ の恒温下に 60 日間保存し, 相分離の状態袁観察すること により行なった。その結果, 相分離を生じたェマルションはいず 剠も合一によるものではなくクリーミングによるものであり，ク リーム相と水相の二相にのみ分離した。そこで図中に示した式に 上りクリーミング安定度 $S$ を定義し，图 12 に招いて維杣を $S$ で表示した。

四から明らかなように，クリーミングに刘する安定性も二次䊑 子の形成によりいちじるしく向上していることが明らかとなっ だっマルション中において油/水界面に液晶のような高次会合 体が形成されると，界面膜の機械的強度が高まるため，合一に対 する安定性が向上することは従来から知られていたが，本実験の 結果ではクリーミングに対しても液晶の形成が有効に作用するこ とが明らかとなった。そして安定性の度合は HLB 変化に比較し て高級アルコール量の変化に大きく影響されることがわかっだ。 これは降伏値,すなわちェマルション中に形成される構造性の強 さと対応した結果となっている。このよらにクリーミングに対し ても液晶の形成が有效に働くのも, 液晶の形成が系沉構造性を与 党，乳化粒子小よび水を固定するためであると考兄られる。

二次粒子の形成によりェマルションに構造性が生じ，安定性が 向上することが明らかとなったが，このほかにも二次粒子形成エ マルションの特性として高い水分保持能が観測された。図 13 は エマルションを一定の厚さの膜にして，恒温恒湿下に放置したと きに失われる水分量を時間に対してプロットしたものであるが， 二次粒子形成エマルションは非形成エマルションにくらべて水分 蒸発率が低い。すなわち水分保持能が高いことが明らかになっ た。この性質もエマルション中に形成された液晶により水が固定 された結果生じたものと考えられる。

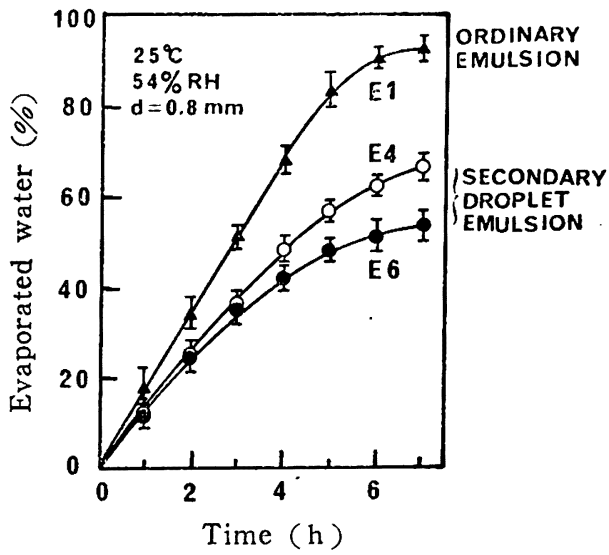

Fig. 13 Effect of secondary droplet formation against the evaporation of water from emulsions

以上述べたように本論文では非イオン界面活性剤, 高級アルコ 一ル，水拉よび流動パラフィンからなる $\mathrm{O} / \mathrm{W}$ 乳化系に批いて， 二次粒子の形成条件, 二次粒子の構造, 二次粒子の形成によるエ マルション物性の変化などを検討し，二次粒子と液晶の関係につ いて考察を行なった。その結果, 二次粒子は非イオン界面活性郕/ 高級アルコール/水からなる閉じたラメラ型液晶により乳化粒子 が固定された構造であり，二次粒子が形成される条件は夜晶の生 成条件之密接阔速しており，二次粒子の形成により，

（1）エマルションに降伏值が生じ見かけ粘度も增大する

（2）エマルションのクリーミングに対する安定性が向上する

（3）エマルションの水分保持能が高くなる

などが明らかとなった。これらの物性変化はいずれも系中分子 の高次会合体である液晶が生成し，乳化粒子および水が固定され た結果生じたものであると考えられ，液晶がェマルションの安定 化に寄与することを確認した。

終りに本研究の機会を与えて下さり，発表を許可していただき ました花王石眮株式会社研究開発本部長常盤文克博士，同東京响 究所長青木修三博士に深く感謝いたします。 


\section{Secondary Droplets Formed in O/W Emulsion—Formation Mechanism and Effects of Their Formation on the Properties of Emulsion- \\ Toshiyuki Suzuki*, Hisao Tsutsumi and Atsuo Ishida \\ Tokyo Research Laboratories, KAO Corporation; Bunka, Sumida-ku, Tokyo 131 Japan}

The structure and formation mechanism of secondary droplets in $\mathrm{O} / \mathrm{W}$ emulsions and the contribution of their formation to the properties of emulsions were investigated. It was found that the secondary droplets were the aggregates of the emulsion droplets surrounded by the liquid crystals of closed lamella type composed of surfactant, fatty alcohol, and water. In order to form the secondary droplets, the presence of an appropriate amount of fatty alcohol and the control of HLB in an appropriate range were necessary. The formation mechanism of the secondary droplets was explained by the dissolved state of fatty alcohol during emulsification. The physicochemical properties of the emulsion chaeged greatly due to the formation of the secondary droplets : a yield value newly appeared; the stability and water-retaining ability of the emulsion were improved.

All of these results are attributed to the fact that the liquid crystals are formed in the continuous phase of the emulsion, thus fixing the emulsion droplets as well as water. 